\title{
An Optimization Approach for Medical Waste Treatment and Landfilling
}

\author{
Thair Jabbar Mizhir Alfatlawi ${ }^{\# 1}$, Zahraa MohammedAlshweikh ${ }^{* 2}$ \\ ${ }^{\# 1}$ Asst. Prof, Department of Civil Engineering, \\ College of Engineering, University of Babylon, Iraq \\ thairjm@yahoo.com \\ ${ }^{* 2}$ M.Sc.student, Department of Civil Engineering, \\ College of Engineering, University of Babylon, Iraq \\ z1mhd1a@gmail.com
}

\begin{abstract}
Solid waste containing hazardous materials is dumped simply into landfills where the rag pickers are exposed to contamination. The disease's prevalence, which may be transmitted by hospital waste, has been alarming in cities near landfills. A mathematical model has been developed to predict the weights of medical waste for the next years (until 2035) using theartificial neural network (ANN). Predicted future medical waste weights of future plan hospitals are found to be up (55444) ton as per bed occupancies $\mathbf{1 0 0 \%}$. Predicted medical waste weights are used later to determine the required treatment plants and landfills capacities and select the optimal number and location of treatment plants and landfills by applying an optimization approach. A total of (2047) optimization sub- problems within (11) scenario are solved to choose the optimum number of landfills and its locations.

The overall minimum treatment and transportation cost is found to be gained by scenario (6), which tests the decision of using (6) landfill sites.Succeeded landfills are located atAlexandria, Imam, AbiGharaq, Hilla, Medhatia, and Shomaly districts, where have acapacity of (9240) ton for each landfill. It is clear to seen scenario (7) and (8) have a slight difference in cost with that for theoverall minimum cost in scenario (6) and they can be selectedif the optimal solution is not applicable for any reasonwithin a permission $10 \%$ and $20 \%$ of total cost.
\end{abstract}

Keyword - Medical waste, Prediction model, ANN,Optimization, Transportation problem.

\section{INTRODUCTION}

Health care activities can generate ahuge amount of waste that may have adversative effects on human health and environment. Medical waste includes all waste generated within health care facilities, research facilities and laboratories relating to medical operations [WHO, 2014 $]^{[1]}$. Medical waste forms a small fraction of the total waste generated in cities, they are mixed with the general waste and make the total municipal solid waste stream that representing a great public health risk.Historical data of generated medical waste, collected from 14 existing governmental hospitals of Babil Governorate, have been used to develop a model to predict the weights of medical waste for the next years (until 2035) using theartificial neural network (ANN). ANN is amathematical technique which based on the structure networks and functions. ANN is considered as a tool of nonlinear statistical data modelling where the composite relationships are modelled or patterns are formed.

Predicted medical waste weights are used later to optimize landfills and treatment plants numbers and locations from the available sites. Siting of treatment plants and landfills is implemented into two stages. In the first stage, siting considerations are appointed for the available sites in Babil Governorate to elect the sites that satisfy environmental, hydrogeological, geological, and governmental criteria. Accordingly, eleven sites, among 80 pre-suggested sites, pass the siting limitations. At the second stage, a constrained linear optimization model is constructed to choose the best number of landfills and its locations that give minimum costs of waste transportation and treatment plants construction.

\section{Medical Waste Prediction Model}

ANN is used to generate a model to predict the future medical waste of Babil Governorate by the benefit of historical data. The available historical data for monthly medical waste is for the year 2010 to 2015 [Directorate of health for Babil Governorate, unpublished reports, 2016 $]^{[2]}$. The suggested model validity is analyzed and tested according to thesuitable statistical viewpoint. In this study, the sigmoid activation function is used to represent the current data. ANN output scale begins at zero value and cannot exceed one for the reason of sigmoid function behavior, in such cases the scaling for data of input and output layers need to be done [CPC-X, $2003]^{[3]}$. Model structure can be briefed as an ANN i,j and k, that (i), (j) and (k) symbolize the neural number of theinput layer, hiddenlayer and output layer, respectively. The neural power software is used to compute the weights and bias factors reduces errors in the output variables. The learning rate, as well as momentum values, were (0.8).Mathematical formulation of medical waste weights prediction have been estimated depending on the following parameters: 
- Bed capacity B.C,

- Bed occupation B.O,

- Population P and

- Area A.

Current study realizes medical waste management problem into mathematical basis where it connects the financial considerations and transportation costs, it is found that the optimization approach is helpful and beneficial for allocating treatment plants and landfills sites where this approach reduces costs significantly.The data transfer from theinput layer to hidden layer and process with activation function and bias value as shown:

$Y_{j}=\beta_{j}+\sum W_{i, j} X_{i}$

$\sigma Y_{j}=1\left(1+e^{-Y_{j}}\right)$

In output layer, the results of hidden layer are received, processed and displayed as anoutput result of theneural system as shown below:

$\boldsymbol{Y}_{\boldsymbol{k}}=\boldsymbol{\beta}_{\boldsymbol{k}}+\sum W_{j, k} \boldsymbol{X}_{\boldsymbol{i}}$

$\sigma Y_{k}=1\left(1+e^{-Y_{k}}\right)$

Where:

$\mathrm{X}_{\mathrm{i}}=$ the input explanatory variables,

$Y_{j}$ and $Y_{k}=$ input and output sigmoid function values, respectively.

$\beta_{j}$ and $\beta_{k}=$ bias values for hidden layers and output layers, respectively.

$\mathrm{W}_{\mathrm{i}, \mathrm{j}}=$ the weights for the connection between neurons for input layers.

$\mathrm{W}_{\mathrm{j}, \mathrm{k}}=$ the weights for the connection between neurons hidden layer.

$\sigma Y_{j}$ and $\sigma Y_{k}=$ result values of hidden layers and output layers, respectively.

Data is divided into two groups: the first group (odd years) is used for training (learning configurations) and the second group (even years) is used for model validation.

\section{A. Training Stage}

Many scenarios, depending on the input parameter values, are tested to choose the most suitable model. Regression coefficient $\left(\mathrm{R}^{2}\right)$ and the root mean square error (RMSE) are adopted as comparison criteria between the examined scenarios. The scenario shown in figure (1) seems to be the best experimented scenario where the model generated by this scenario gives the highest value of $\mathrm{R}^{2}(98 \%)$ and aminimum value of RMSE $(258.67$ $\mathrm{kg}$ ). Bed capacity (B.C) represents the most important parameter for generating themodel, composes approximately $35.9 \%$, while bed occupation for the next year $\left(\mathrm{B} \mathrm{O}_{\mathrm{i}+1}\right)$ composes $2.7 \%$ of importance. Figure (2) gives the importance of the input parameters for the succeeded scenario.

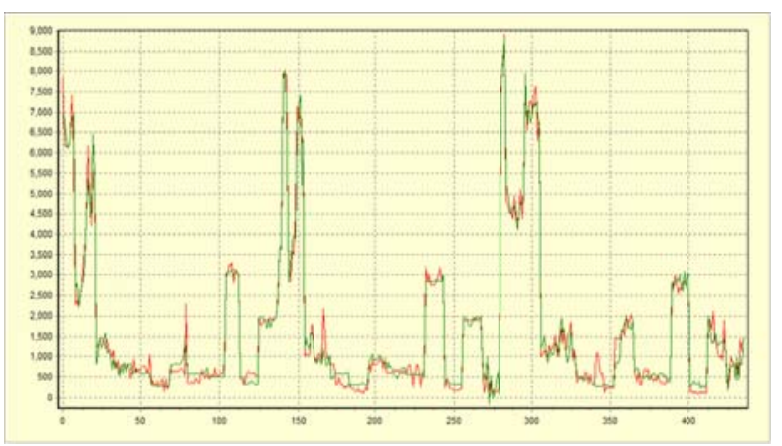

—Observed weight_—Calculated weight

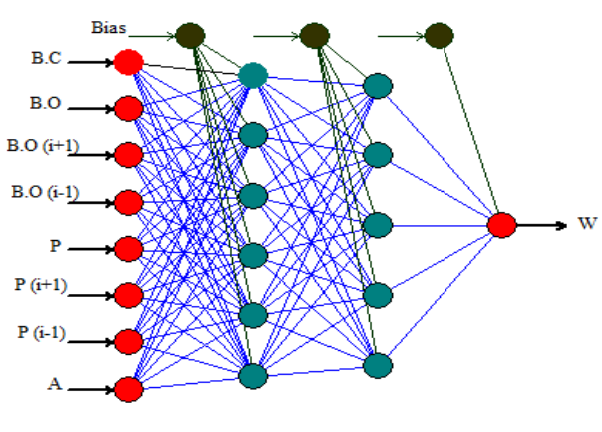

$\mathrm{RMSE}=258.67 \mathrm{~kg}$
Average $\mathrm{R}^{2}=0.981$

Figure (1): ANN structure of MW predictionfor succeeded scenario. 


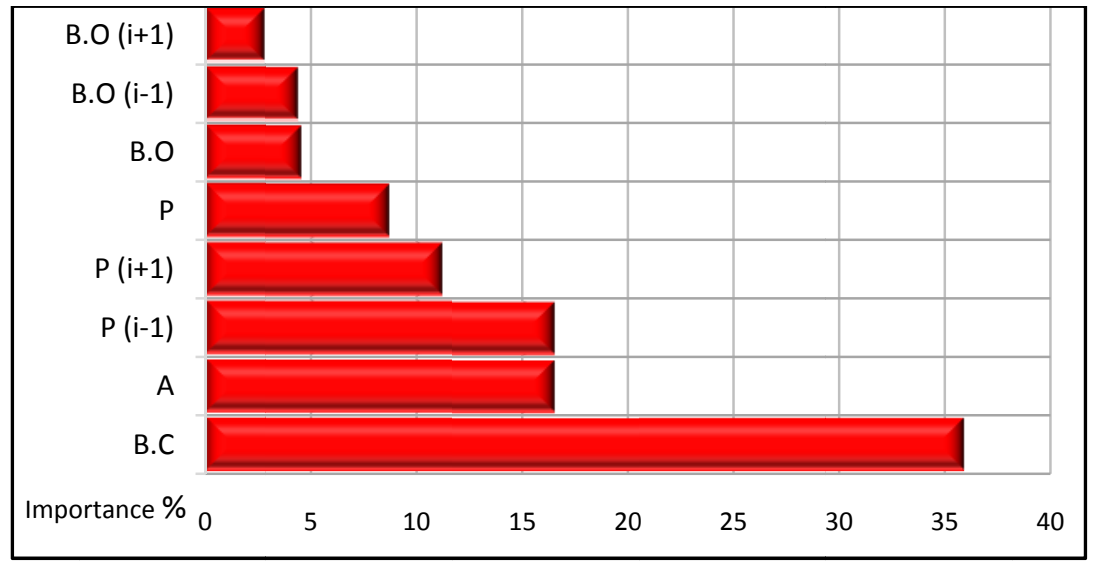

Figure (2): Importance of parameters of input layers for succeeded scenario.

\section{B. Validation Stage}

In this stage, the succeeded model in training stage is applied to the remaining data (even years), figure (3) shows a comparison between the historical medical waste and that generated by ANN model. Succeeded scenario generates the medical waste weights successfully where it coincides the historical medical waste with aregression coefficient of $88 \%$.

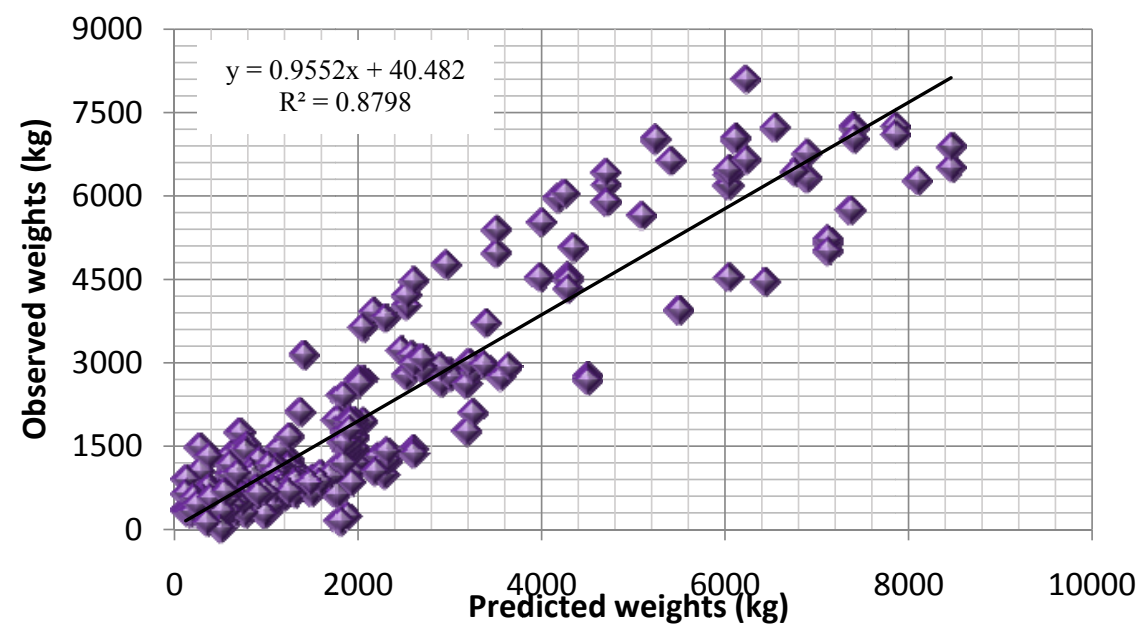

Figure (3): Predicted - observed relationship of medical waste for succeeded scenario in validation stage.

In addition to regression coefficient, other statistical measures are used to inspect concordance for observed values in comparing with calculated values, such as mean square error MSE, root means square error RMSE, mean absolute percentage error MAPE, maximum percentage error maxPE, mean absolute error MAE, and maximum absolute error maxAE. These statistical measures have been determined for the calculated values of weights as follow:

$\begin{array}{lllllll}\text { MSE } & =384506 \mathrm{~kg}^{2} & \mathrm{MAPE} & =35.7 \% & \mathrm{MAE} & =398.6 & \mathrm{Kg} \\ \mathrm{RMSE} & =620 & \mathrm{Kg} & \operatorname{maxPE}=590 \% & \operatorname{maxAE}=2124.7 & \mathrm{Kg}\end{array}$

\section{III.Predicted Medical Waste Weights}

The prediction model takes into consideration the urban development and population growth. To reach the specified criteria of Ministry of Health, a number of health care facilitiesHCF is assumed to be (1 HCF/ 50000 Capita). Bed capacity has been determined by the structural plan for restoration and development of health care system for a long-term enhanced plan of Babil Governorate (SPBG) [GIS unit, Babil Governorate, unpublished study, 2010] $]^{[4]}$, bed occupation is adopted to be $100 \%$ during computations. The annual population has been estimated depending on $2.7 \%$ annual growth rate [Directorate of statistics for Babil Governorate, 2016] ${ }^{[5]}$.

Each district has been dealt separately, and the data analysis has been done for each main districts with their own subdistricts. Table (1) shows the input parameters of Babil Governorate in the ANN model. Predicted medical waste of Babil Governorate districts is shown in figure(4). 
Table (1): ANN model input parameters for Babil Governorate.

\begin{tabular}{|c|c|c|c|c|c|}
\hline District & $\begin{array}{c}\text { Area } \\
\left(\mathrm{km}^{2}\right)\end{array}$ & $\begin{array}{c}\text { Population of } \\
2035(\text { capita })\end{array}$ & $\begin{array}{c}\text { Bed capacity } \\
\text { B.C }\end{array}$ & $\begin{array}{c}\text { No. of } \\
\text { HCF }\end{array}$ & $\begin{array}{c}\text { Total bed } \\
\text { capacity B.C }\end{array}$ \\
\hline Hilla & 161 & 962,215 & 261 & 19 & 4959 \\
\hline Kifl & 526 & 243,237 & 261 & 5 & 1305 \\
\hline Abi-Gharaq & 191 & 188,290 & 261 & 4 & 1044 \\
\hline Mahawel & 600 & 202,531 & 215 & 4 & 860 \\
\hline Mashroa & 834 & 220507 & 215 & 4 & 860 \\
\hline Imam & 75 & 63,839 & 215 & 1 & 215 \\
\hline Neel & 158 & 102,127 & 215 & 2 & 430 \\
\hline Hashimia & 5 & 61,462 & 168 & 2 & 336 \\
\hline Qasem & 334 & 275,220 & 168 & 6 & 1008 \\
\hline Medhatia & 502 & 234,938 & 168 & 5 & 840 \\
\hline Shomaly & 503 & 151,229 & 168 & 3 & 504 \\
\hline Taleaa & 301 & 67,510 & 168 & 1 & 168 \\
\hline Musayeb & 257 & 200374 & 176 & 5 & 880 \\
\hline Sadda & 8 & 155,814 & 176 & 3 & 528 \\
\hline Jurf al-Nasr & 388 & 51,684 & 176 & 1 & 176 \\
\hline Alexandria & 249 & 244,827 & 176 & 5 & 880 \\
\hline Sum. & 5,092 & $3,425,804$ & - & 70 & 14,993 \\
\hline
\end{tabular}

\section{Total predicted medical waste weights}

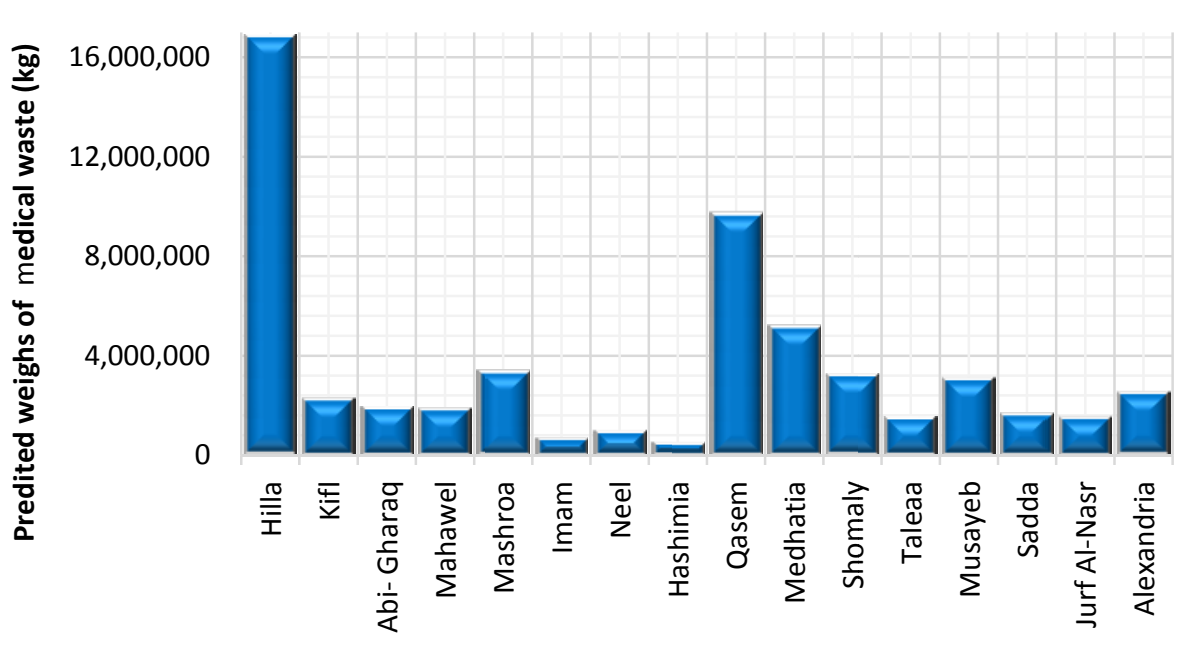

Figure (4): Total predicted medical waste weights for a period (2015- 2035) for Babil Governorate hospitals. 


\section{IV.Design, Siting ANd OPERATION Of TReatment Plants and LandfiLls}

Table (2) shows treatment plant units and landfills calculations depending on ANN prediction model results for bed occupation B.O $=100 \%$.

Table (2):Treatment plant units and landfills calculations depending on ANN prediction model

\begin{tabular}{|l|l|}
\hline Bed occupation (B.O) & $100 \%$ \\
\hline Total predicted medical waste weight $(\mathrm{kg})$ & $55,444,417$ \\
\hline Total predicted medical waste volume $\left(\mathrm{m}^{3}\right)$ & 369,629 \\
\hline medical waste volume at shredder $\left(\mathrm{m}^{3}\right)$ & 179,270 \\
\hline medical waste volume at autoclave $\left(\mathrm{m}^{3}\right)$ & 98,599 \\
\hline medical waste volume at incinerator $\left(\mathrm{m}^{3}\right)$ & 4,930 \\
\hline medical waste volume at encapsulation $\left(\mathrm{m}^{3}\right)$ & 21,625 \\
\hline Area of landfill $\left(\mathrm{m}^{2}\right)$ & 8,074 \\
\hline
\end{tabular}

Many criteria, like environmental, political, economic, hydrological and hydrogeological criteria, are specified landfill selection. Many limitations are put to ensure these criteria, like:

- Landfills should be placed farther than $1000 \mathrm{ft}$. $(304.8 \mathrm{~m})$ up gradient from water wells [Sener, $2004]^{[6]}$.

- Due to the movement of leachate and rock slope failure which can be influenced by thegeologic structure of dump layer, the best location of thelandfillis flat rolling hills that not underwent to floods.

- Landfills should be constructed on a distance farther than $5000 \mathrm{~m}$ from urban centers unless there are natural barriers [Al-Anbari et al., 2013] $]^{[7]}$.

- A buffer zone of $500 \mathrm{~m}$ is acceptable for roads around landfill site, despite that, the distance greater than $1 \mathrm{~km}$ from roads and highways should be avoided because the expensive cost of constructing road networks [Allen et al., 2001] ${ }^{[8]}$.

- The buffer zone is determined as $500 \mathrm{~m}$ for rivers or lakes and up to $250 \mathrm{~m}$ swamp areas [AlAnbari et al., 2013] ${ }^{[7]}$.

- Distance from sensitive lands as cemeteries, historical sites, and religious sites must be more than $1500 \mathrm{~m}$ [Gisi, 2010] $]^{[9]}$.

- The distance of $3030 \mathrm{~m}$ must be taken as a buffer zone from theairport [El-Alfy et al., $2010]^{[10]}$.

Siting of treatment plants and landfills is implemented into two stages. In the first stage, siting considerations are appointed on the available sites in Babil Governorate to elect all sites that satisfy criteria such as governmental regulations, ground water, hydrogeological, geological, soil characteristics, topographical and natural resources criteria.In the second stage, a constrained optimization model is constructed to choose the best number of landfills and their locations. The objective function of the optimization model aims to minimize the total cost of treatment plants, supplying and installing, and medical waste transportation costs. Figure (5) shows the available locations for treatment plants construction and landfilling (up to 80 locations) according to the structural plan for restoration and development of health care system for a long-term enhanced plan of Babil Governorate (SPBG), 2010. 


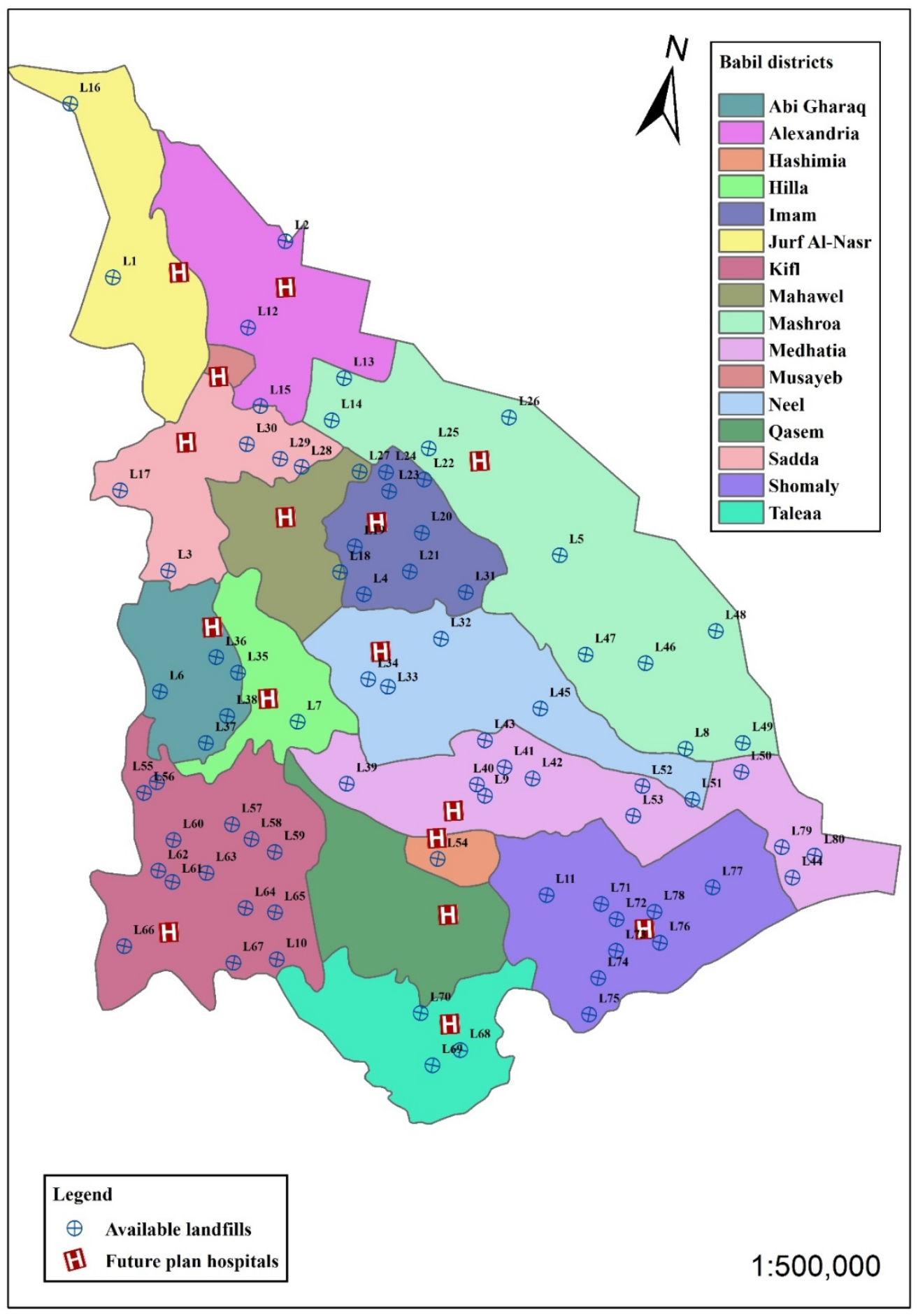

Figure (5): Available landfills sites according to SPBG.

Within the first stage, the buffer zones criteria are limited to $5000,250,500,30,75,250,1500$, 3000 and $500 \mathrm{~m}$ away from urban centers, swamp areas, roads, power lines, oil pipes, liquid gas, religion site, airports and railways, respectively. Accordingly, eleven sites within Babil Governorate borders pass the siting limitations. Succeeded sites from the first stage that shown in figure (6) will be optimized in the second stage. 


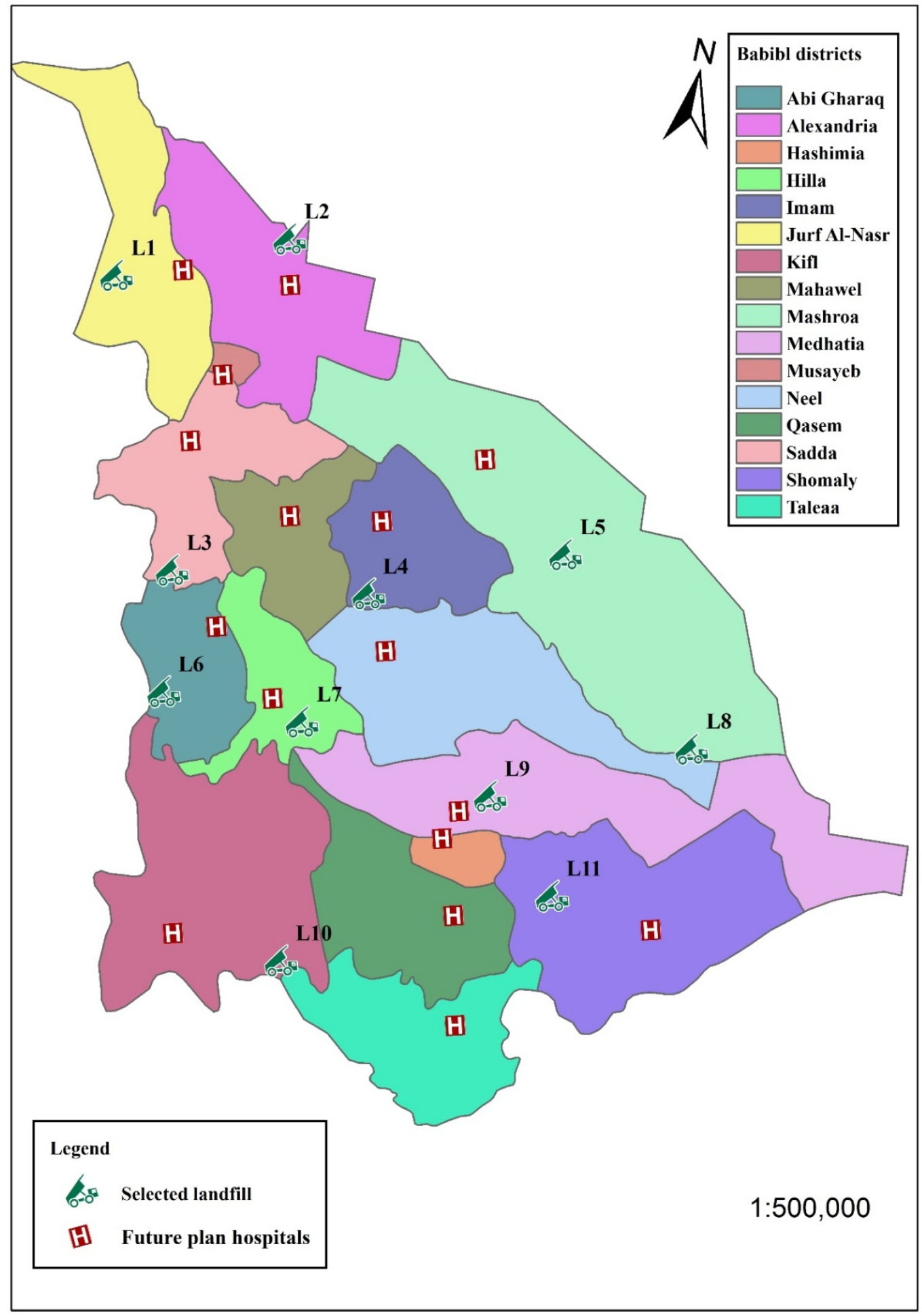

Figure (6): Succeeded sites from the first stage.

\section{OPTIMization Of EleCted Sites}

\section{A. Simplex Linear Programming}

Linear program solver LiPS 1.11.1 is used. The solver is intended for solving linear, integer and goal programming problems. In thecase of large input data, the solver will use LU factorization method. In this study, 11 scenarios have been tested to reach the minimum cost of treatment and landfilling for themedical waste of Babil Governorate. Each scenario will mathematically evaluate the cost due to choosing a certain number of landfills. As example, scenario 1 tests the decision of using one landfill, scenario 2 tests the decision of using two landfill sites, and so on. A total of 
(2047) optimization sub- problems are solved to choose the optimum number of landfills and its locations.

B. Treatment Plants and Transportation Costs

The cost of supplying and installing treatment plants are assumed depending on the utilizing of machinery and equipment prices at sales services via web portals. The prices of treatment units according to the total input weight rates of medical waste are detailed in table (3).

Table (3): Prices of treatment units [https://www.alibaba.com ,2016 $]^{[11]}$.

\begin{tabular}{|c|c|c|c|}
\hline $\begin{array}{c}\text { Capacity of treatment } \\
\text { unit (kg/ hr.) }\end{array}$ & $\begin{array}{c}\text { Shredder } \\
\text { (\$) }\end{array}$ & $\begin{array}{c}\text { Autoclave } \\
\mathbf{( \$ )}\end{array}$ & $\begin{array}{c}\text { Incinerator } \\
\mathbf{( \$ )}\end{array}$ \\
\hline$\geq 200$ & 10,000 & 300,000 & - \\
\hline $150-350$ & - & - & 50,000 \\
\hline $100-150$ & 6,000 & 150,000 & 25,000 \\
\hline $50-100$ & 5,000 & - & - \\
\hline$<50$ & 3,000 & - & - \\
\hline $30-100$ & - & - & 12,000 \\
\hline $30-60$ & - & 20,000 & - \\
\hline$<30$ & - & 20,000 & 9,800 \\
\hline
\end{tabular}

Transportation costs are estimated based on the assumption that truck yielding a total of 3-8 ton per transit. The total transportation costs can be approximated depending on the following: If the distance between the source and the destination is less than 30 miles $(48.3 \mathrm{~km})$, the transportation cost will be $0.46 \$ / \mathrm{km}$.ton. If the distance varies between 30 to 200 mile $(48.3-321.8 \mathrm{~km})$, the transportation cost will be $0.38 \$ / \mathrm{km}$.ton. The transportation cost will be $0.31 \$ / \mathrm{km}$.ton if the distance is more than 200 mile $(321.8 \mathrm{~km})$ [(Feizollahi et al., 1995) ${ }^{[12]}$ and (Directorate of AlMusayeb municipality, unpublished reports, 2016) $\left.{ }^{[13]}\right]$.

Table (4) displays the transportation cost in $\$ / \mathrm{km}$.ton from each Babil Governorate hospitals towards each destination (treatment plants and landfills). The distances that exceed $48.3 \mathrm{~km}$ are indicated by red color, the required distances are calculated by the real measure using GISARCMap 10.3.

Table (4): Transportation costs $(\$ / \mathrm{km}$. ton) from HCF to the elected treatment plants and landfills.

\begin{tabular}{|c|c|c|c|c|c|c|c|c|c|c|c|}
\hline Sources & L1 & L2 & L3 & L4 & L5 & L6 & L7 & L8 & L9 & L10 & L11 \\
\hline Hilla & 18.88 & 19.25 & 8.27 & 7.21 & 16.56 & 5.53 & 1.89 & 21.41 & 12.09 & 13.28 & 17.34 \\
\hline Kifl & 27.64 & 29.48 & 18.41 & 19.86 & 22.85 & 4.23 & 12.57 & 23.07 & 17.52 & 17.22 & 19.32 \\
\hline Abi Gharaq & 18.52 & 20.01 & 3.66 & 7.89 & 18.07 & 12.27 & 6.46 & 20.54 & 16.31 & 5.65 & 21.80 \\
\hline Mahawel & 15.05 & 14.06 & 6.57 & 5.58 & 14.09 & 10.94 & 10.41 & 19.43 & 17.43 & 18.59 & 19.30 \\
\hline Mashroa & 20.89 & 14.95 & 16.82 & 8.99 & 6.28 & 20.07 & 16.18 & 17.99 & 17.04 & 22.63 & 18.46 \\
\hline Imam & 18.34 & 15.07 & 10.91 & 3.71 & 9.46 & 14.01 & 10.91 & 19.47 & 14.95 & 18.85 & 20.83 \\
\hline Neel & 19.36 & 21.46 & 11.59 & 3.05 & 10.35 & 11.44 & 5.54 & 16.28 & 9.05 & 16.54 & 14.98 \\
\hline Hashimia & 27.23 & 25.90 & 19.30 & 12.96 & 15.71 & 15.96 & 9.25 & 13.46 & 3.25 & 10.23 & 6.29 \\
\hline Qasem & 30.28 & 29.14 & 18.66 & 16.86 & 19.16 & 18.57 & 12.48 & 14.75 & 6.33 & 9.03 & 5.10 \\
\hline Medhatia & 26.62 & 24.98 & 18.99 & 11.94 & 14.10 & 16.14 & 9.16 & 12.23 & 1.77 & 11.76 & 6.38 \\
\hline Shomaly & 35.38 & 32.64 & 25.08 & 18.38 & 19.53 & 22.71 & 20.60 & 9.43 & 10.60 & 18.80 & 5.29 \\
\hline Taleaa & 34.45 & 33.64 & 22.45 & 18.43 & 20.25 & 18.56 & 17.25 & 18.46 & 11.75 & 9.42 & 8.21 \\
\hline Musayeb & 7.38 & 7.69 & 10.20 & 13.32 & 19.61 & 16.31 & 18.01 & 25.11 & 20.88 & 24.62 & 25.79 \\
\hline Sadda & 9.19 & 11.42 & 6.60 & 11.90 & 19.87 & 12.76 & 15.30 & 24.63 & 19.46 & 22.07 & 24.33 \\
\hline $\begin{array}{c}\text { Jurf Al- } \\
\text { Nasr }\end{array}$ & 3.38 & 5.64 & 15.19 & 18.89 & 19.94 & 21.35 & 19.52 & 29.23 & 25.48 & 29.17 & 30.39 \\
\hline Alexandria & 8.82 & 2.35 & 15.62 & 16.13 & 19.51 & 21.56 & 22.11 & 25.67 & 22.96 & 28.27 & 27.81 \\
\hline Legend & $\begin{array}{l}\text { No. = transportation cost for a distance less than } 48.3 \mathrm{~km} . \\
\text { No. = transportation cost for a distance more than } 48.3 \mathrm{~km} .\end{array}$ & & \\
\hline
\end{tabular}




\section{Formulation of Treatment Plants and Landfills Siting Problem}

To determine optimal locations for treatment plants and landfills within Babil Governorate, the transportation in addition to treatment plant units' cost must be minimized. Hospitals (assumed to be at the centre of their own district) products an amount of medical waste to supply destinations, each landfill has a potential capacity for maximum weights of previously predicted medical waste. The objective function of present study problem can be reprostate as:

$\beta_{m, r}=\operatorname{Min} \sum_{r=1}^{C_{r}^{n}}\left[\sum_{i=1}^{16} \sum_{j=1}^{11}\left(C_{i, j}^{t} x_{i, j}\right)+\sum_{m=1}^{11} C_{m}^{p}\right]$

$\gamma_{m}=\operatorname{Min} \sum_{m=1}^{11} \beta_{m, r}$

$\delta=\operatorname{Min} \sum_{m=1}^{11} \gamma_{m}$

The objective function is objected to supply and demand constraints:

$$
\begin{aligned}
& \sum_{i=1}^{16} x_{i, j} \leq L_{c_{j}} \\
& \sum_{j=1}^{11} x_{i, j}=S_{i}
\end{aligned}
$$

$x_{i, j} \geq 0$

Where:

$\beta_{m, r}=$ Minimum cost of medical waste transportation and treatment for sub- problem in one scenario.

$m=$ Number of scenarios, $m=1,2,3, \ldots 11$.

$\mathrm{C}_{r}^{n}=\frac{n !}{r !(n-r) !}=$ Combinations $\mathrm{r}$ from $\mathrm{n}$.

$r=$ Number of sub- problems to be solved.

$\mathrm{n}=$ Number of elected landfills $=11$.

$i=$ Number of sources, $i=1,2,3, \ldots 16$.

$j=$ Number of destinations, $j=1,2,3, \ldots 1$.

$C^{t}{ }_{i, j}=$ Cost of medical waste transportation from hospital (i) to landfill (j).

$x_{i, j}=$ Binary decision variable representing the product (medical waste) from hospital (i) that demanded to landfill (j).

$C_{m}^{p}=$ Cost of treatment plant scenario (m).

$\gamma_{m}=$ Minimum cost of medical wastetransportation and treatment for scenario (m).

$\delta=$ Overall minimum cost of medical wastetransportation and treatment.

$L_{c_{j}}=$ Capacity of landfill (j).

$S_{i}=$ Medical wasteweighs from source (i).

The solution of theproblem is implemented for (2047) sub-problems for (11) scenario, landfills capacities are assumed to be equal in the same scenario. The overall minimum between this (2047) sub- problems $(\delta)$ is considered as the optimum solution and the corresponding number of thetreatment plant and their locations are the optimum between other experimented scenarios.Table (5) shows a summary of the results of the linear programming problem of landfills siting in Babil Governorate. 
Table (5): Optimum landfills.

\begin{tabular}{|c|c|c|c|c|c|c|c|c|}
\hline 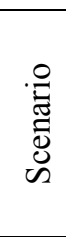 & 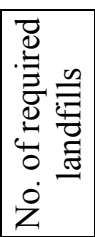 & 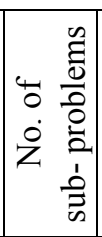 & 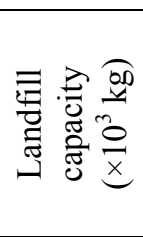 & 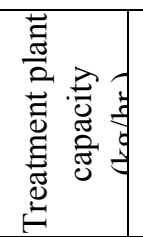 & $\begin{array}{l}\text { Min. } \\
\text { cost } \\
(\$)\end{array}$ & $\begin{array}{l}\text { Accepted } \\
\text { landfills }\end{array}$ & $\begin{array}{l}\text { Max. } \\
\text { cost } \\
(\$)\end{array}$ & $\begin{array}{l}\text { Accepted } \\
\text { landfills }\end{array}$ \\
\hline 1 & 1 & 11 & 55,444 & 316.5 & $\begin{array}{c}936,42 \\
0\end{array}$ & L7 & $\begin{array}{c}1,553,13 \\
4\end{array}$ & L1 \\
\hline 2 & 2 & 55 & 27,722 & 158.2 & $\begin{array}{c}861,88 \\
2\end{array}$ & L7-L9 & $\begin{array}{c}1,537,08 \\
0\end{array}$ & L1-L2 \\
\hline 3 & 3 & 165 & $18,481.4$ & 105.5 & $\begin{array}{c}850,39 \\
3\end{array}$ & L4-L7-L11 & $\begin{array}{c}1,407,26 \\
2\end{array}$ & L1-L2-L5 \\
\hline 4 & 4 & 330 & 13,861 & 79.1 & $\begin{array}{c}671,05 \\
1\end{array}$ & $\begin{array}{l}\text { L2-L7-L9- } \\
\text { L11 }\end{array}$ & $\begin{array}{c}1,120,16 \\
4\end{array}$ & $\begin{array}{l}\text { L1-L2-L3- } \\
\text { L5 }\end{array}$ \\
\hline 5 & 5 & 462 & $11,088.8$ & 63.3 & $\begin{array}{c}700,16 \\
0\end{array}$ & $\begin{array}{l}\text { L2-L6-L7- } \\
\text { L9-L11 }\end{array}$ & $\begin{array}{c}1,116,30 \\
9\end{array}$ & $\begin{array}{l}\text { L1-L2-L3- } \\
\text { L4-L5 }\end{array}$ \\
\hline 6 & 6 & 462 & $9,240.7$ & 52.7 & $\begin{array}{c}513,83 \\
8 \\
\end{array}$ & $\begin{array}{l}\text { L2-L4-L6- } \\
\text { L7-L9-L11 }\end{array}$ & 866,483 & $\begin{array}{l}\text { L1-L2-L3- } \\
\text { L4-L5-L6 }\end{array}$ \\
\hline 7 & 7 & 330 & 7,920.6 & 45.2 & $\begin{array}{c}550,80 \\
4\end{array}$ & $\begin{array}{c}\text { L2-L4-L6- } \\
\text { L7-L9-L10- } \\
\text { L11 }\end{array}$ & 820,214 & $\begin{array}{l}\text { L1-L2-L3- } \\
\text { L4-L5-L6- } \\
\text { L8 }\end{array}$ \\
\hline 8 & 8 & 165 & $6,930.5$ & 39.6 & $\begin{array}{c}580,71 \\
4\end{array}$ & $\begin{array}{l}\text { L2-L3-L4- } \\
\text { L6-L7-L9- } \\
\text { L10-L11 }\end{array}$ & 796,435 & $\begin{array}{l}\text { L1-L2-L3- } \\
\text { L4-L5-L6- } \\
\text { L7-L8 }\end{array}$ \\
\hline 9 & 9 & 55 & $6,160.5$ & 35.2 & $\begin{array}{c}637,18 \\
2\end{array}$ & $\begin{array}{l}\text { L2-L3-L4- } \\
\text { L5-L6-L7- } \\
\text { L9-L10-L11 }\end{array}$ & 772,841 & $\begin{array}{l}\text { L1-L2-L3- } \\
\text { L4-L5-L8- } \\
\text { L9-L10-L11 }\end{array}$ \\
\hline 10 & 10 & 11 & $5,544.4$ & 31.7 & $\begin{array}{c}676,69 \\
1\end{array}$ & $\begin{array}{l}\text { L2-L3-L4- } \\
\text { L5-L6-L7- } \\
\text { L8-L9-L10- } \\
\text { L11 }\end{array}$ & 729,450 & $\begin{array}{l}\text { L1-L2-L3- } \\
\text { L4-L5-L6- } \\
\text { L8-L9-L10- } \\
\text { L11 }\end{array}$ \\
\hline 11 & 11 & 1 & $5,040.4$ & 28.8 & $\begin{array}{c}712,58 \\
8\end{array}$ & $\begin{array}{l}\text { L1-L2-L3- } \\
\text { L4-L5-L6- } \\
\text { L7-L8-L9- } \\
\text { L10-L11 }\end{array}$ & 712,588 & $\begin{array}{l}\text { L1-L2-L3- } \\
\text { L4-L5-L6- } \\
\text { L7-L8-L9- } \\
\text { L10-L11 }\end{array}$ \\
\hline \multicolumn{3}{|c|}{ Total sub-problems } & \multicolumn{6}{|l|}{2047} \\
\hline \multicolumn{4}{|c|}{ Overall min. cost occurs at } & \multicolumn{3}{|c|}{ L2-L4-L6-L7-L9-L11 } & Cost $(\$)$ & 513,838 \\
\hline \multicolumn{4}{|c|}{ Overall max. cost occurs at } & L1 & & & Cost $(\$)$ & $1,553,134$ \\
\hline
\end{tabular}

Figure (7) shows the variation of minimum cost with the number of landfills. The overall minimum is found to be gained by scenario (6) with landfills located at Alexandria (L2), Imam (L4), Abi- Gharaq (L6), Hilla (L7), Medhatia (L9) and Shomaly (L11). It is important to record that scenario (7) with landfills located at Alexandria (L2), Imam (L4), Abi- Gharaq (L6), Hilla (L7), Medhatia (L9), Kifl (L10) and Shomaly (L11) and scenario (8) with landfills located at Alexandria (L2), Sadda (L3), Imam (L4), Abi- Gharaq (L6), Hilla (L7), Medhatia (L9), Kifl (L10) and Shomaly (L11), have a slight difference in cost with that for overall minimum cost in scenario (6) and they can be considered as succeeded scenarios. Figure (8) shows the (462) sub- problems solved in present study for scenario (6) to reach the minimum scenario cost. 


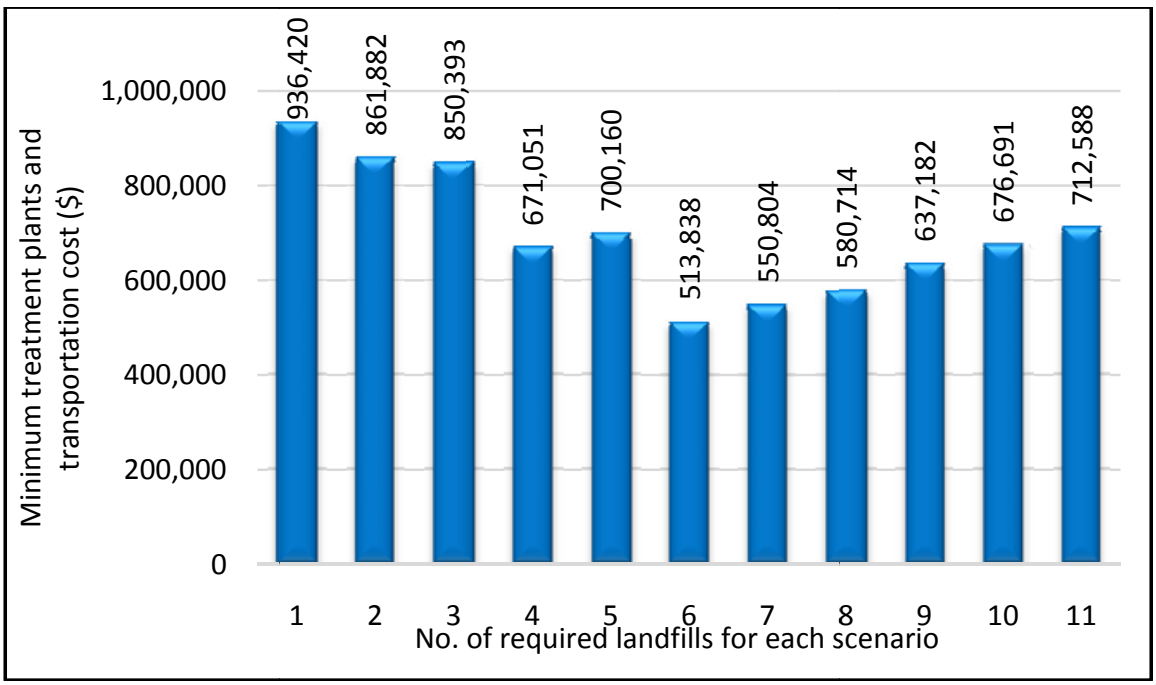

Figure (7): Variation of total cost with the number of required landfills.

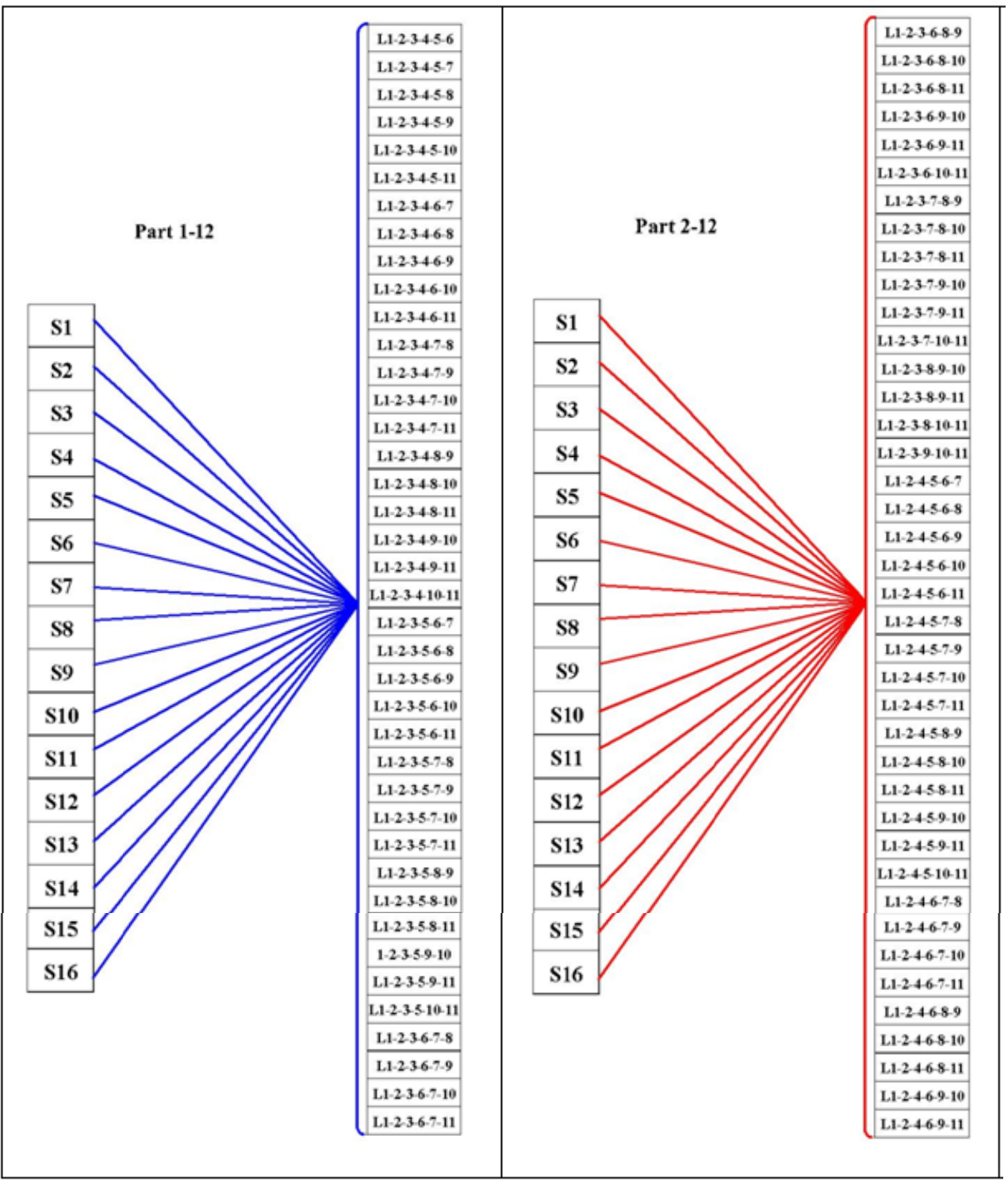




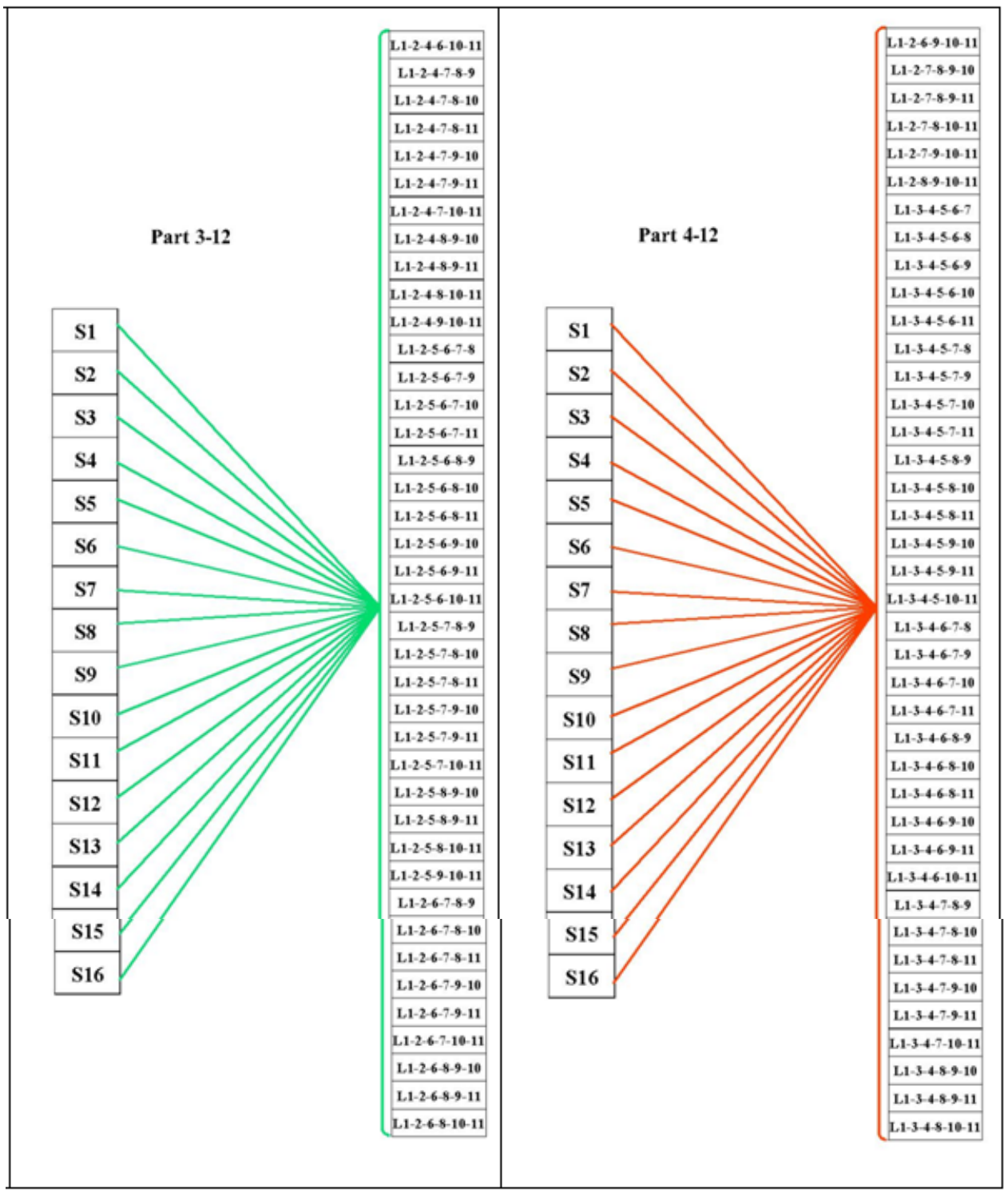

Figure (8): Optimization sub-problems corresponding to scenario 6 . 


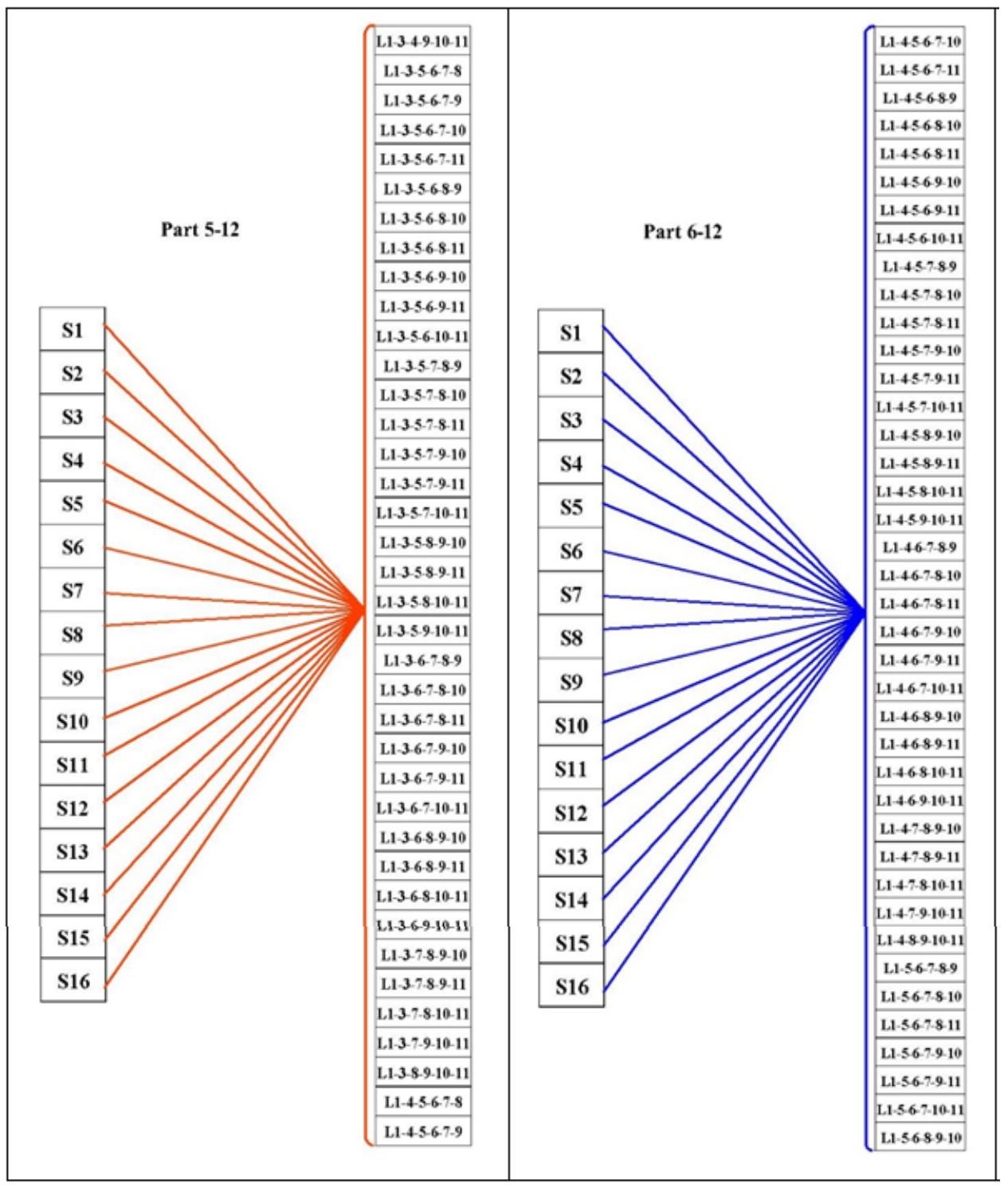




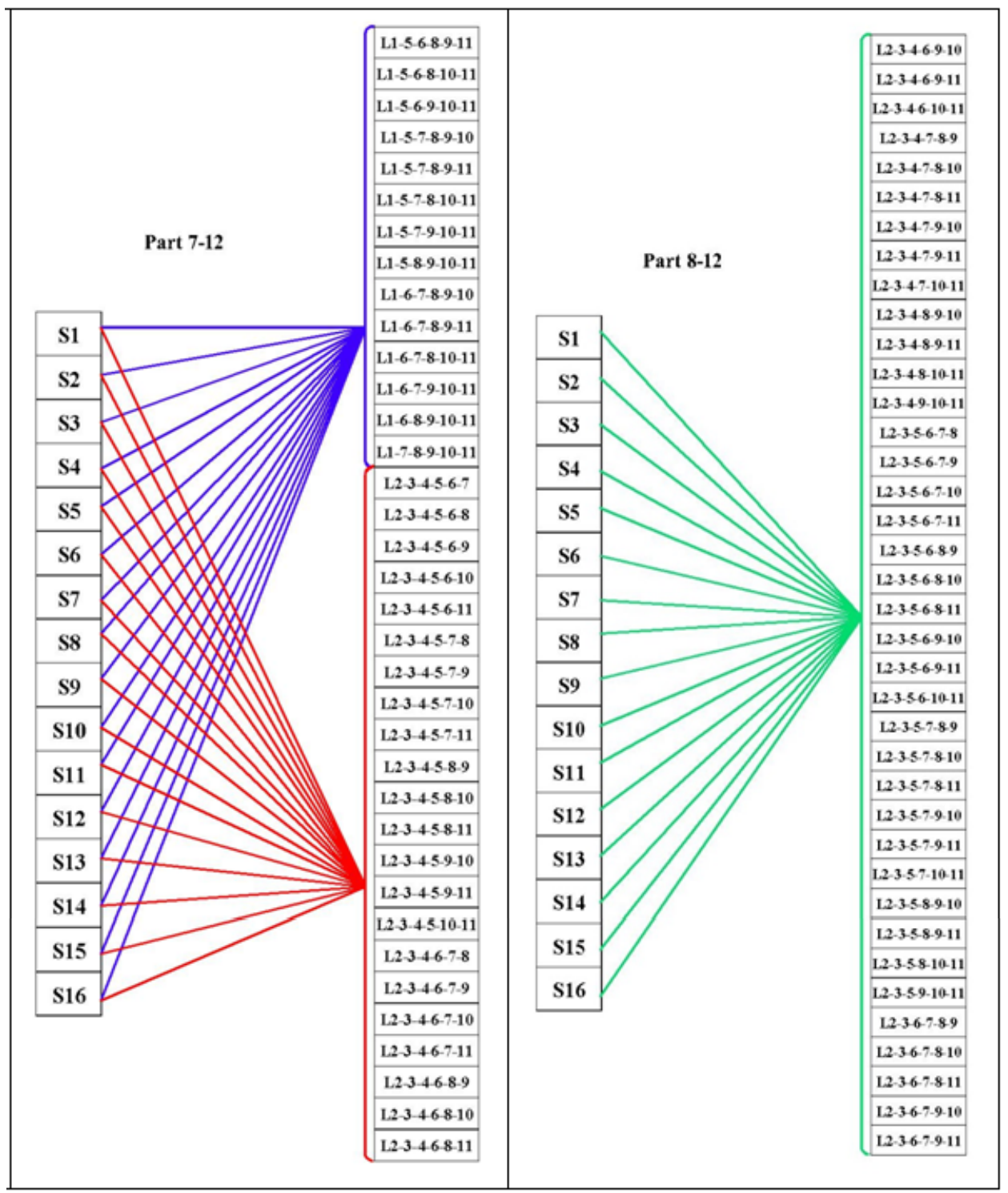

Continued to figure (8): Optimization sub-problems corresponding to scenario 6 . 


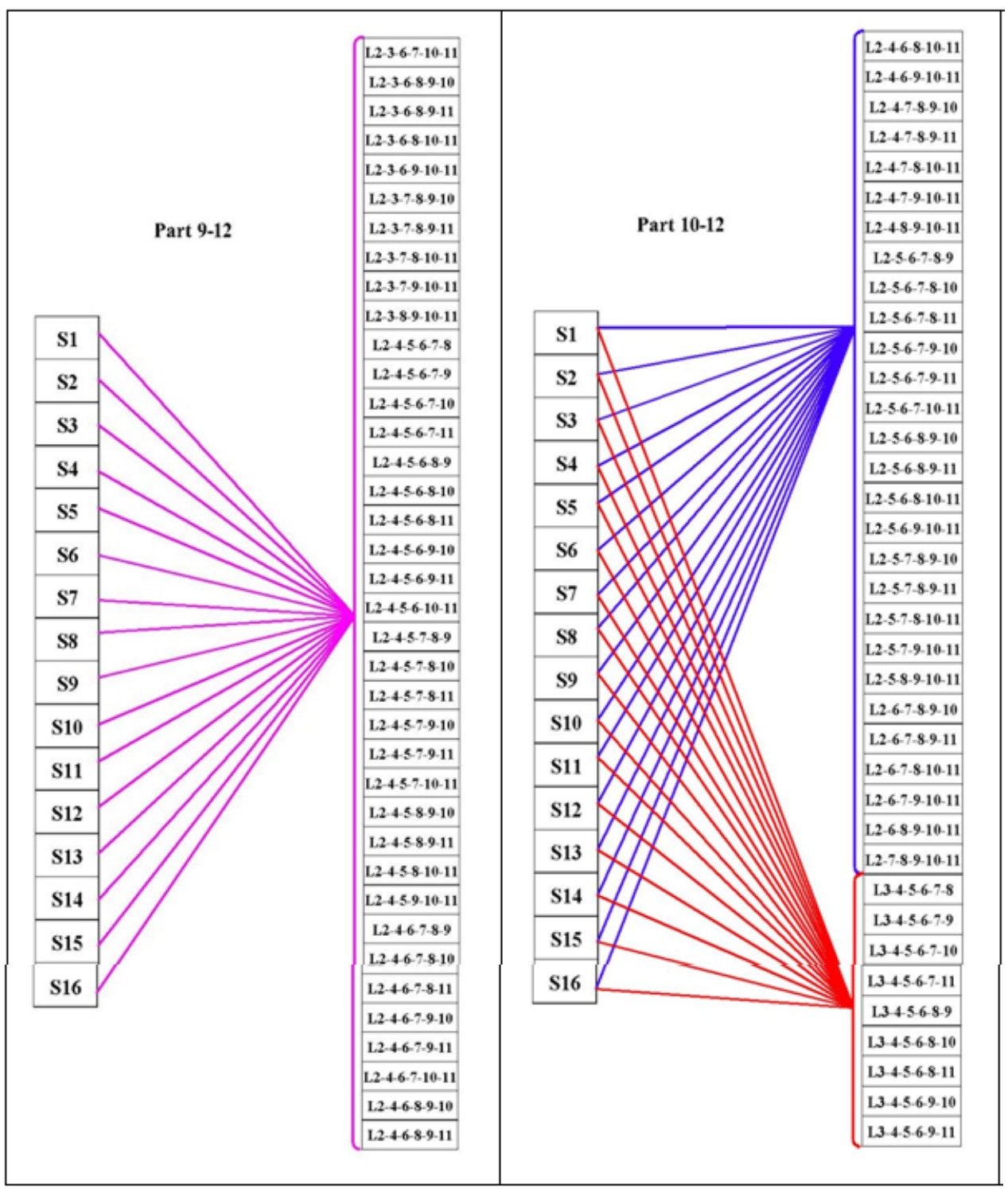




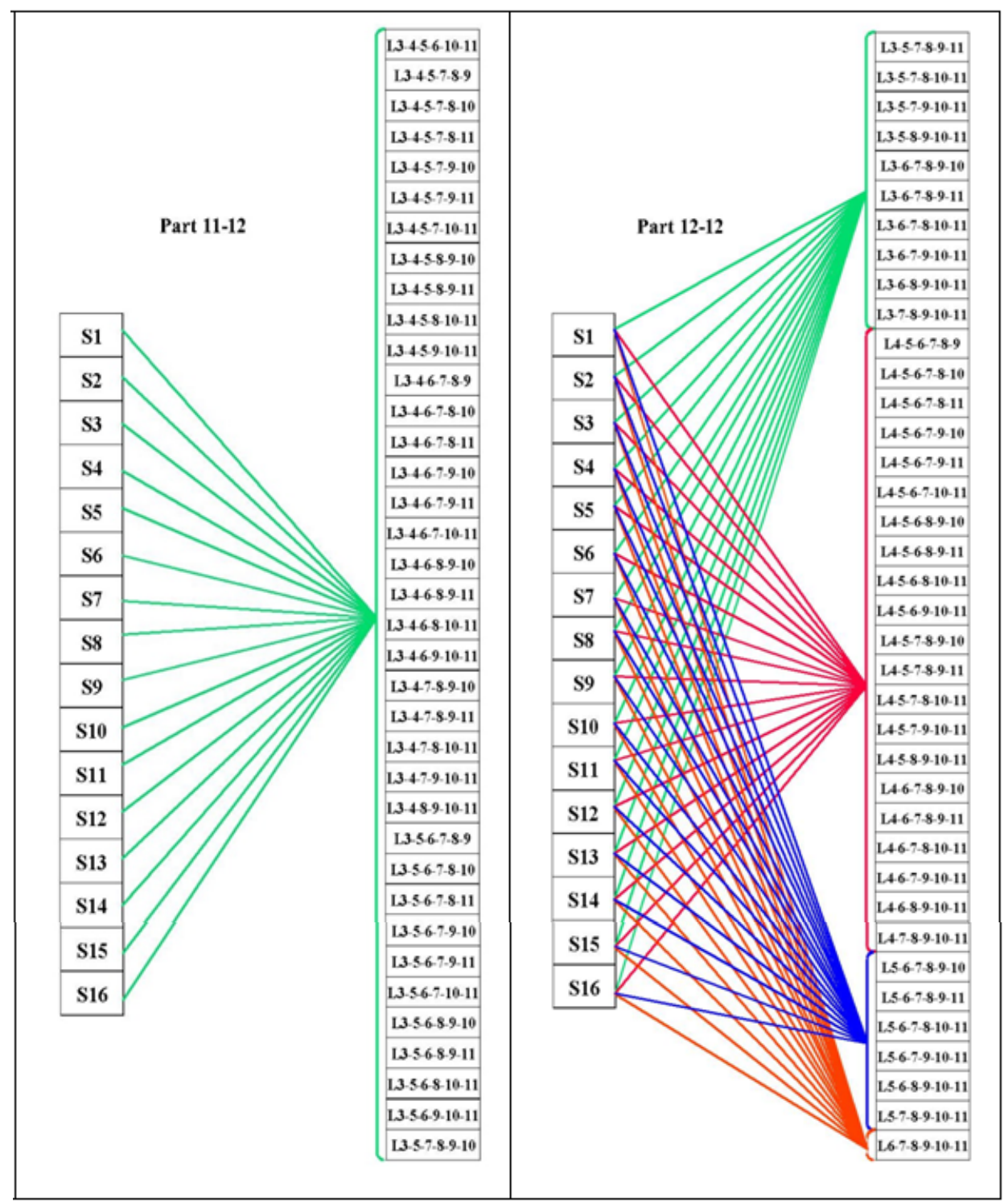

Continued to figure (8): Optimization sub-problems corresponding to scenario 6.

Figure (9) displays the optimum medical waste movement directions towards landfills as a percentage of total landfill capacity $\left(\mathrm{L}_{\mathrm{c}}\right)$ for the scenarios $(6)$. 


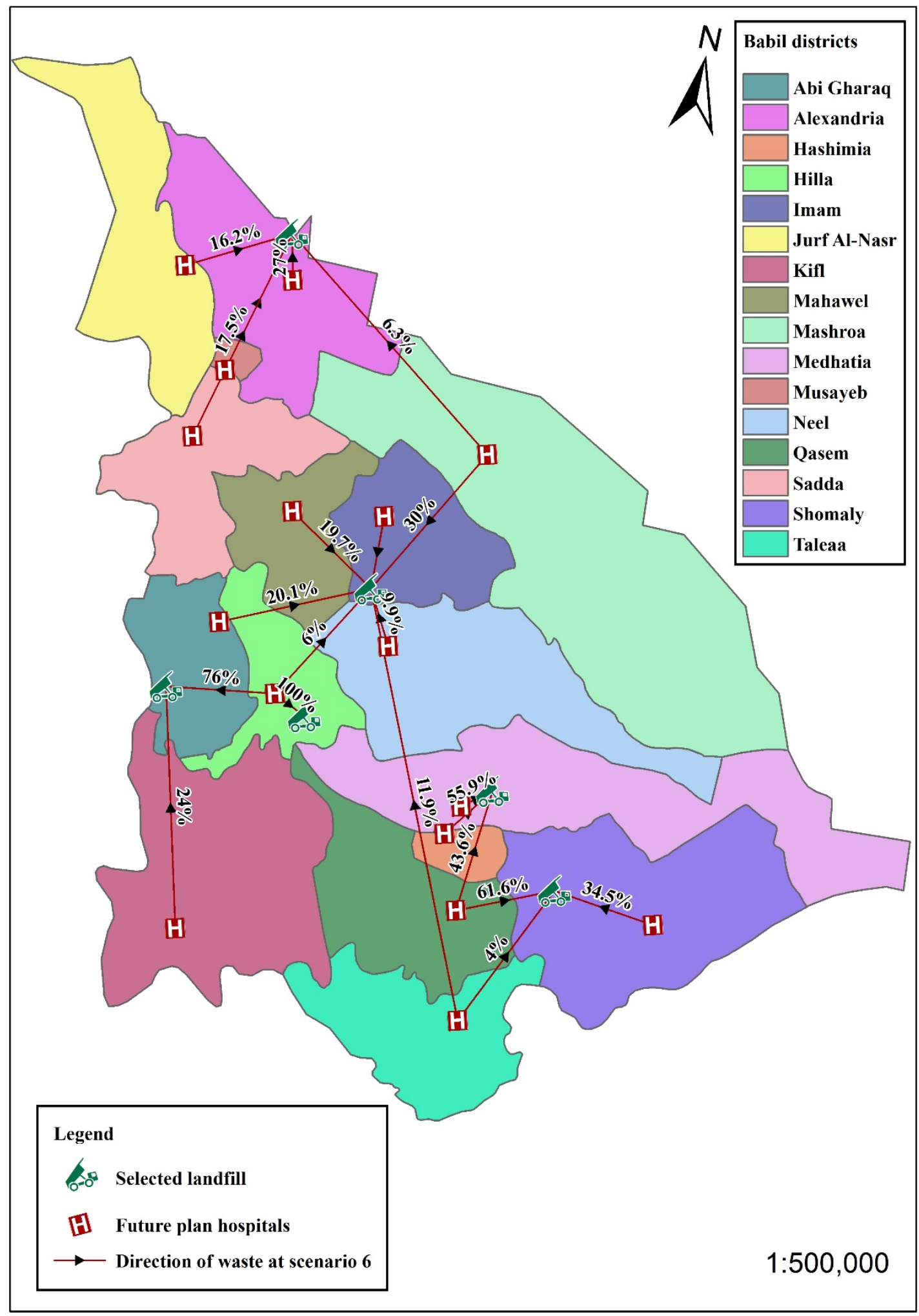

Figure (9): Optimum medical waste movement towards landfills corresponding to scenario 6. 
Figure (10) shows the succeeded optimization sub-problem that solved corresponding to scenario 6. It can also be noticed that outgoing medical waste proportion contributes the total capacity of thelandfill.

\begin{tabular}{|c|c|c|c|}
\hline Production=16812 ton & Hilla (S1) & & $\mathrm{Lc1}=9240.7$ ton \\
\hline Production $=2222$ ton & Kifl (S2) & & $\mathrm{Lc2}=9240.7$ ton \\
\hline Production $=1857$ ton & Abi-Gharaq (S3) & & $\mathrm{Lc3}=9240.7$ ton \\
\hline Production $=1821$ ton & Mahawel (S4) & & $\mathrm{Lc4}=9240.7$ ton \\
\hline Production $=3351$ ton & Mashroa (S5) & & Lc5 $=9240.7$ ton \\
\hline Production $=225$ ton & Imam (S6) & & Lc6 $=9240.7$ ton \\
\hline Production $=916$ ton & Neel (S7) & & $\mathrm{Lc} 7=9240.7$ ton \\
\hline Production $=47$ ton & Hashimia (S8) & $0.5 \%$ & $\mathrm{Lc8}=9240.7$ ton \\
\hline Production=9719.2ton & Qasem (S9) & & Lc9 $=9240.7$ ton \\
\hline Production $=5162$ ton & Medhatia (S10) & & Lc10 $=9240.7$ ton \\
\hline Production $=3188$ ton & Shomaly (S11) & & Lc11 $=9240.7$ ton \\
\hline Production $=1463$ ton & Taleaa (S12) & & \\
\hline Production $=3049$ ton & Musayeb (S13) & & \\
\hline Production $=1620$ ton & Sadda (S14) & & \\
\hline Production $=1494$ ton & Jurf Al-Nasr(S15) & & \\
\hline Production $=2498$ ton & Alexandria (S16) & & \\
\hline
\end{tabular}

Figure (10): The optimum proportion of outgoing medical waste towards selected landfills corresponding scenario 6 .

\section{The Inability to Satisfy the Optimum Scenario:}

There are many reasons make the optimum scenario cannot satisfy, this inability may be due to the changes in land use, overestimated or unexpected population growth because of exceptional conditions or immigration, whether or not the structural future plan is accomplished, financial considerations and other reasons else.Alternative for such cases is studied to produce new choices that minimize the cost, this analysis done by assuming that there is up to $10 \%$ and $20 \%$ of total cost of scenario (6) is permitted. All scenarios of a cost increment less than $10 \%$ and $20 \%$ of the total cost are suggested to be alternatives if a shortage of optimum scenario site will occur to provide the required flexibility to the decision maker.

Permission of $10 \%$ of total cost for succeeded landfills corresponding to scenario 6 brings out 13 alternative sites (each consists of 6 active landfills) distributed over all districts, selected landfills for scenario (7) also validate at cost release $10 \%$ of total cost. Likewise, 58 alternative sites are brought up a cost release of $20 \%$ distributed to all districts in thegovernorate. It can be seen that alternative sites if there is a release to $10 \%$ and $20 \%$ increment in the total cost, will appear in scenario (7) and (8), while no other scenario produce alternative sites. Figure (11) shows the succeeded landfills combinations for $10 \%$ and $20 \%$ of scenario 6 total cost permissions. 

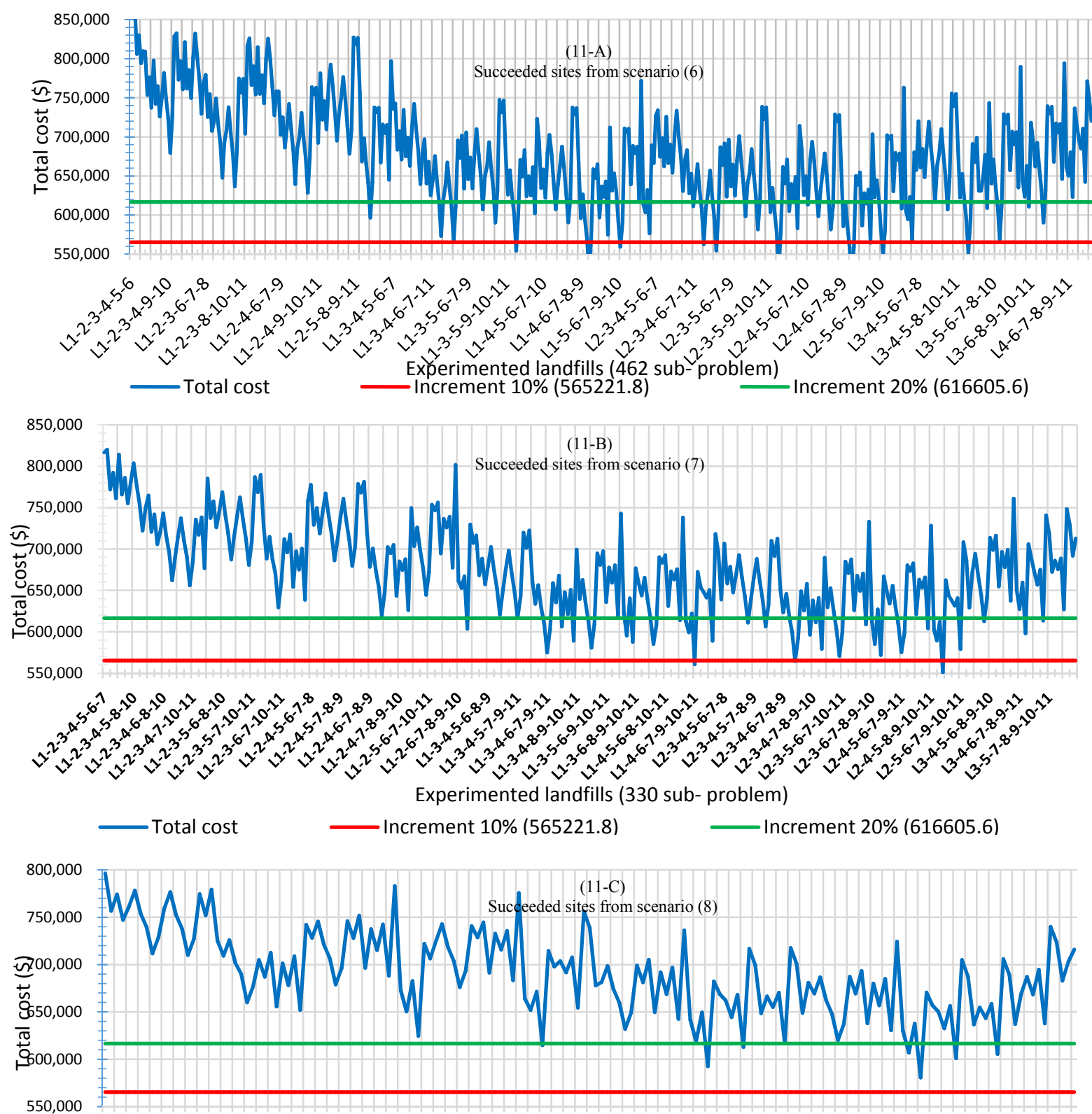

550,000

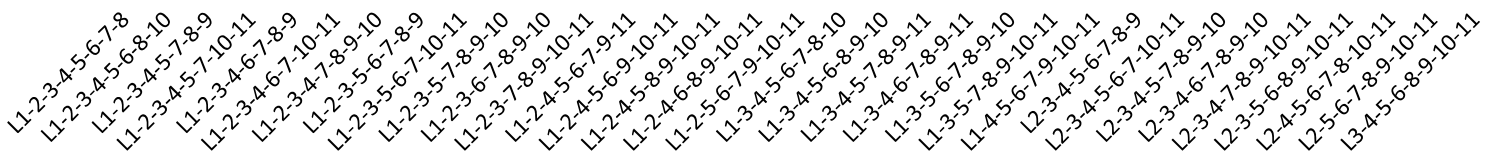

Experimented landfills (165 sub- problem)

Total cost

Increment 10\% (565221.8)

Increment 20\% (616605.6)

Figure (11): Succeeded landfills combinations for $10 \%$ and $20 \%$ of scenario 6 total cost is permitted.

\section{VI.CONCLUSION}

Based on the results obtained from this study, many conclusions can be inferred. For medical waste prediction model, it can be seen that the generated model is influenced significantly by the order of consecutive monthsforbed capacity, area, population and bed occupation. Also, Landfills locations play an essential role in solid waste management cost where the cost of treatment and landfilling of medical waste are not directly proportionalto the number of landfills, i.e. if landfills number increase, it is not necessary to result in an increase in medical waste management cost. One also can conclude that the optimum solution is not unique if slight differences in scenarios costs are ignored. 
For the case study focused throughout this study, medical waste weights are predicted until 2035 as per bed occupancies (100\%) for health care facilities according to government future plan. The developedANN model succeeded model to match historical records with $\mathrm{R}^{2}$ equal to $(98 \%)$ and RMSE of $(258.67 \mathrm{~kg})$. Results and comparisons showed that using an optimization approach with ANN prediction seem to be beneficial to provide the decision makers multiple, flexible and economic choices for medical waste treatment and management.

\section{REFERENCES}

[1] World Health Organization, (WHO), 2nd edition. "Safe Management of Wastes from Health-Care Activities", edited by Y. Chartier, J. Emmanuel, U. Pieper, A. Prüss, P. Rushbrook, R. Stringer, W. Townend, S. Wilburn, and R. Zghondi, Geneva, Switzerland.2014.

[2] Directorate of health for Babil Governorate. 2016

[3] CPC-X Software, "Neural Power User Guide".2003.

[4] Babil Governorate, GIS unit, unpublished study. 2010.

[5] Directorate of statistics for Babil Governorate. 2016.

[6] B. Sener, "Landfill Site Selection By Using Geographic Information Systems", M.Sc. Thesis, Department of Geological Engineering, Turkey. 2004

[7] R. Al-Anbari, A. Alnakeeb and A. Abdulredha, "Landfill Site Selection for Kerbala Municipal Solid Wastes by Using Geographical Information System Techniques", Engineering and Technical Journal, Vol. 32, Part A,No.13.2013.

[8] A. Allen, G. Brito, P. Caetano, C. Costa, V. Cummins, J. Donnelly, C. Fernandes, S. Koukoulas, V. O’Donnell, C. Robalo and D. Vendas, Final project report, "The Development of a GIS Model for the Location of Landfill Sites in Ireland and Portugal".2001.

[9] S. Gisi and G. Feo, " Using an Innovative Criteria Weighting Tool for Stakeholders Involvement to Rank MSW Facility Sites with the AHP", Elsevier Ltd, Waste Management, Vol. 30, pp. 2370-2382.2010.

[10] Z. ElAlfy, R. Elhadary and A. Elashry, "Integrating GIS and MCDM to Deal with Landfill Site Selection", International Journal of Engineering and Technology Vol., 10, No., 6.2010.

[11] Sales Services via Web Portals, 2016.Available:https://www.alibaba.com.

[12] F. Feizollahi, D. Shropshireand D. Burton, "Waste Management Facilities Cost Information for Transportation of Radioactive and Hazardous Materials", Idaho National Engineering Laboratory, Radioactive Waste Technical Support Program.1995.

[13] Directorate of Al-Musayeb municipality, unpublished reports, 2016. 